\title{
REDUCTION OF BLEEDING AFTER HEART OPERATIONS THROUGH THE PROPHYLACTIC USE OF EPSILON-AMINOCAPROIC ACID
}

Thomas J. Vander Salm, MD

Shubjeet Kaur, MD ${ }^{\mathrm{b}}$

Robert A. Lancey, $\mathrm{MD}^{\mathrm{a}}$

Okike N. Okike, $\mathrm{MD}^{\mathrm{a}}$

A. Thomas Pezzella, MD $^{\mathrm{a}}$

Russell F. Stahl, MD

Lisa Leone, $\mathrm{BSN}^{\mathrm{a}}$

Jian-Ming Li, MD ${ }^{\mathrm{a}}$

C. Robert Valeri, $\mathrm{MD}^{\mathrm{c}}$

Alan D. Michelson. MD
Excessive postoperative bleeding after heart operations continues to be a source of morbidity. This prospective double-blind study evaluated epsilonaminocaproic acid as an agent to reduce postoperative bleeding and investigated its mode of action. One hundred three patients were randomly assigned to receive either $30 \mathrm{gm}$ epsilon-aminocaproic acid (51 patients) or an equivalent volume of placebo (52 patients). In a subset of these patients (14 epsilon-aminocaproic acid, 12 placebo), tests of platelet function and fibrinolysis were performed. Results: By multivariate analysis, three factors were associated with decreased blood loss in the first 24 hours after operation: epsilon-aminocaproic acid versus placebo $(647 \mathrm{ml}$ versus $839 \mathrm{ml}$, $p=0.004)$, surgeon 1 versus all other surgeons $(582 \mathrm{ml}$ versus $978 \mathrm{ml}, p=$ 0.002 ), and no intraaortic balloon versus intraaortic balloon pump use (664 $\mathrm{ml}$ versus $1410 \mathrm{ml}, p=0.02$ ). No significant differences in platelet function could be demonstrated between the two groups. Inhibited fibrinolysis, as reflected by less depression of the euglobulin clot lysis and no rise in D-dimer levels, was significant in the epsilon-aminocaproic acid group compared with the placebo group. Conclusion: The intraoperative use of epsilon-aminocaproic acid reduces postoperative cardiac surgical bleeding. (J Thorac Cardiovasc Surg 1996;112:1098-107)
B leeding after heart operations continues to be a concern for cardiac surgeons. Treatment during the operation with aprotinin reduces bleeding, but that drug is expensive and may cause such complications as renal failure, coronary graft occlusion, myocardial infarction, and allergic reaction. ${ }^{1-4}$ Treatment of bleeding after heart operations with epsilon-aminocaproic acid (EACA) was reported in 1967 by Sterns and Lillehei. ${ }^{5}$ Several other authors have since confirmed EACA's effectiveness, but the drug appears to be regarded as secondary in importance to aprotinin. ${ }^{6-10}$ In our previous investigation of the use of low-dose EACA, we found that it

From the Division of Cardiothoracic Surgery, ${ }^{a}$ Department of Pediatrics, ${ }^{\mathrm{d}}$ and Department of Anesthesia, ${ }^{\mathrm{b}}$ University of Massachusetts Medical Center, Worcester, Mass., and the Naval Blood Research Laboratory, ${ }^{c}$ Boston University School of Medicine, Boston, Mass.

Received for publication Jan. 22, 1996; revisions requested March 13, 1996; revisions received April 23, 1996; accepted for publication June 4, 1996.

Address for reprints: Thomas J. Vander Salm, MD, Department of Surgery, University of Massachusetts Medical School, 55 Lake Avenue, N. Worcester, MA 01655-0333.

Copyright 1996 by Mosby-Year Book, Inc.

$0022-5223 / 96 \$ 5.00+0 \quad \mathbf{1 2 / 1 / 7 5 5 2 0}$ diminished bleeding after cardiac operations. ${ }^{11} \mathrm{We}$ and others have since begun prophylactic use of the drug in larger doses. ${ }^{10}$ This randomized, prospective double-blind study compared patients receiving high-dose EACA with a control group of patients receiving a placebo and investigated the mechanism of action of EACA during cardiopulmonary bypass (CPB).

\section{Material and methods}

After protocol approval by the Human Subjects Research Committee of the University of Massachusetts Medical Center, informed consent was obtained from 103 patients. Consenting patients were then prospectively randomly assigned to receive EACA (Amicar; Lederle Laboratories, Pearl River, N.Y.; 51 patients) or a similar volume of $0.9 \%$ saline solution (52 patients) in a doubleblind study. Random assignment by means of a random number table and drug preparation were performed by the hospital pharmacy. Surgeons, perfusionists, anesthesiologists, and all laboratory personnel were unaware whether each patient received placebo or EACA. Patients in the treatment group received a total of $30 \mathrm{gm}$ EACA: $10 \mathrm{gm}$ intravenously before skin incision. $10 \mathrm{gm}$ intravenously after heparin administration, and $10 \mathrm{gm}$ intravenously at the discontinuation of $\mathrm{CPB}$ but before protamine administration. Patients in the control arm group received saline solution in the same volumes and with the same timing. Heparin was administered per protocol at 
$400 \mathrm{U} / \mathrm{kg}$, and incremental doses were given during the operation to maintain the activated clotting time at greater than 400 seconds. Protamine for heparin neutralization was administered per protocol at $1 \mathrm{mg} / 100 \mathrm{U}$ total heparin dose. Patients requiring emergency operations, those with abnormal results of preoperative bleeding studies, and those who were pregnant were excluded from the study; no other exclusion criteria were used. Eligible patients included those needing coronary bypass or valve operations. Closure time was defined as the time from termination of CPB to the application of the dressing. The dose of EACA was chosen on the basis of our previous study, ${ }^{11}$ in which a total of $11 \mathrm{gm}$ EACA was administered, and on the larger $30 \mathrm{gm}$ dose administered by Daily and colleagues. ${ }^{10}$ Patient body surface areas in the study population ranged 1.40 to $2.78 \mathrm{~m}^{2}$ (mean $1.96 \mathrm{~m}^{2}$ ). Postoperative chest tube drainage was not reinfused. The trigger for postoperative transfusion was a hematocrit lower than $25 \%$.

For all patients, routine preoperative and postoperative hematologic and coagulation studies performed consisted of complete blood cell count, prothrombin time, partial thromboplastin time, bleeding time, and thrombin time. Postoperative blood loss, as measured by chest tube drainage, and blood component therapy were recorded. In a subset of 26 patients (14 EACA, 12 control), various hemostatic tests were performed. These tests were of two types, those evaluating platelet function and those measuring fibrinolysis. These included fibrinogen level, antiplasmin level, D-dimer level, euglobulin lysis time, antithrombin III level, and platelet count measured before operation, after heparin administration, 45 minutes after initiation of CPB, 5 minutes after protamine administration, 2 hours after operation, and 24 hours after operation. Bleeding time was measured before operation and 2 hours after operation. These assays were all performed as described elsewhere. ${ }^{12}$ After the Swan-Ganz catheter (Baxter Healthcare Corp., Edwards Div., Irvine, Calif.) had been placed, $5 \mathrm{ml}$ blood was withdrawn from it before blood samples were drawn.

In addition and at the same time intervals, whole blood flow cytometry (performed as described elsewhere ${ }^{13}$ ) was used to measure the expression of platelet surface glycoprotein (GP) Ib, GPIIb-IIIa complex, fibrinogen binding to the GPIIb-IIIa complex, and P-selectin. The following monoclonal antibodies were used in these studies: S12 (Centocor, Inc., Malvern, Pa.) is directed against Pselectin, ${ }^{14,15}$ a component of the $\alpha$-granule membrane of resting platelets that is expressed on the platelet surface membrane only after platelet degranulation and secretion. ${ }^{14,16} 6 \mathrm{D} 1$ (provided by Barry S. Coller, Mount Sinai Medical Center, N.Y.) is directed against the von Willebrand factor binding site on the amino terminal domain of platelet membrane GP Ib $\alpha{ }^{17,18}$ Y $2 / 51$ (DAKO Corp., Carpenteria, Calif.) is directed against platelet membrane GPIIIa. ${ }^{19}$ 7E3 (also provided by Coller) is directed at the fibrinogen binding site on the GPIIb-IIIa complex ${ }^{20}$ F26 (provided by Harvey Gralnick, National Institutes of Health Clinical Center, Bethesda, Md.) is directed against a conformational change in fibrinogen bound to the GPIIb-IIIa complex. ${ }^{21,22} \mathrm{~S} 12,6 \mathrm{D} 1,7 \mathrm{E} 3$, and F26 were biotinylated as described elsewhere. ${ }^{13}, 23$ Fluorescein iso-
Table I. Preoperative patient characteristics

\begin{tabular}{lccc}
\hline & $\begin{array}{c}\text { EACA } \\
(n=51)\end{array}$ & $\begin{array}{c}\text { Control } \\
(n=52)\end{array}$ & $p$ \\
\hline Male/female ratio & $35 / 16$ & $40 / 12$ & NS \\
Age (yr) & $64.7 \pm 12.1$ & $64.2 \pm 12.4$ & NS \\
Reoperation (no.) & $5(9.8 \%)$ & $7(13.5 \%)$ & NS \\
Hematocrit (preoperative) $(\%)$ & $40.4 \pm 4.9$ & $40.5 \pm 4.0$ & NS \\
PT (preoperative) (sec) & $13.0 \pm 0.98$ & $13.1 \pm 0.93$ & NS \\
PTT (preoperative) (sec) & $43.3 \pm 18$ & $43.9 \pm 22$ & NS \\
BSA (m $\left.{ }^{2}\right)$ & $1.98 \pm 0.27$ & $1.94 \pm 0.24$ & NS \\
\hline
\end{tabular}

Values are mean \pm standard deviation. $N S$, Not significant; $P T$, prothrombin time; PTT, partial thromboplastin time; $B S A$, body surface area.

thiocyanate-conjugated $\mathrm{Y} 2 / 51$ was purchased from DAKO.

In a pilot study we compared preoperative blood obtained by peripheral venipuncture with preoperative blood obtained through the Swan-Ganz catheter and found no statistical difference in the binding of monoclonal antibodies S12, 6D1, 7E3, and F26 $(n=9)$. Drawing the blood through the Swan-Ganz catheter did not result in platelet activation or other platelet surface changes, so blood was obtained from the Swan-Ganz catheter in all subsequent studies.

Statistical methods. The primary outcome variable was blood loss through the chest tubes at 24 hours. Baseline characteristics and operative data for the control and EACA groups were compared by an unpaired $t$ test for continuous variables and by $\chi^{2}$ tests for association of categoric variables. A multivariate analysis was used to adjust for confounding factors in the blood loss correlation and to determine the factors independently predictive of blood loss. Because of skewed (nonnormal) distribution of blood loss and large, unequal variances, the natural log of blood loss, rather than the actual blood loss, was used for the calculation of statistical significance. Differences were considered significant at a $95 \%$ confidence level ( $\alpha$ $=0.05$ ).

\section{Results}

Preoperative patient variables did not differ significantly between the EACA and control groups with respect to age, sex, reoperations, or preoperative clotting factors; all of which were normal in both groups (Table I). The following operative variables also did not differ significantly between the two groups: surgeon, cardioplegia temperature, operation performed, and use of internal mammary grafts (Table II). CPB time, however, was significantly longer in the EACA group (148 minutes EACA vs 129 minutes control, $p=0.02$ ), as was crossclamp time (85 minutes EACA vs 73 minutes control, $p=$ 0.04 ). Mean closure time was 58 minutes in the EACA group and 54 minutes in the control group $(p=0.2)$ Closure time for surgeon 1 was 55 minutes; for the other surgeons it was 58 minutes $(p=0.3)$. 


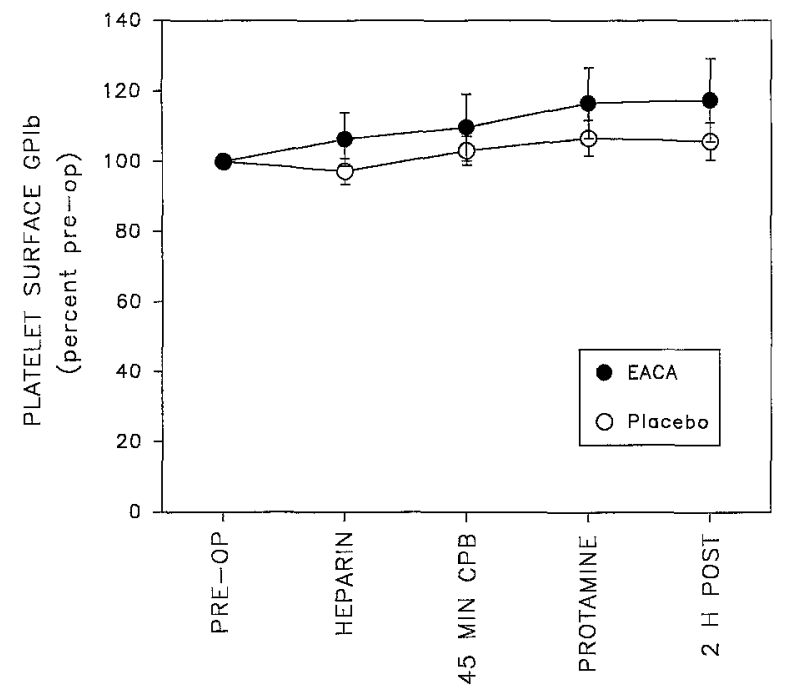

Fig. 1. Platelet surface expression of GPIb (von Willebrand factor receptor) did not change significantly during or after CPB, irrespective of whether patients received EACA (closed circles) or placebo (open circles). Platelet surface GPIb was determined at indicated time points by whole blood flow cytometry with monoclonal antibody 6D1. PRE-OP, Preoperative; HEPARIN, 5 minutes after initial heparin administration; $45 M I N C P B, 45$ minutes into CPB; PROTAMINE, 5 minutes after protamine administration; 2 H POST, 2 hours after skin closure. Data are mean \pm standard error of the mean; $n=13$ patients for EACA and $n=10$ patients for placebo. Actual preoperative values (mean flourescence \pm standard error of the mean) were $33.8 \pm 2.4$ in EACA group and $37.0 \pm$ 1.8 in placebo group.

In the subset of 26 patients who underwent more extensive hematologic testing, platelet surface GP expression and the fibrinolytic system were evaluated. By whole blood flow cytometry before, during, and after CPB, platelet surface expression of GPIb (von Willebrand factor receptor) was found not to change significantly irrespective of whether the patients received EACA (Fig. 1). Platelet surface expression of the GPIIb-IIIa complex (fibrinogen receptor) was also unchanged during or after $\mathrm{CPB}$ irrespective of the use of EACA (Fig. 2). In addition, we used monoclonal antibody F26 to measure directly the amount of fibrinogen bound to the platelet surface GPIIb-IIIa complex. Platelet activation results in a conformational change in the GPIIb-IIIa complex that allows fibrinogen to bind to this complex. As a result of its binding to the GPIIb-IIIa complex, fibrinogen in turn changes conformation. Only when fibrinogen is in this new
Table II. Operative variables of EACA and control groups

\begin{tabular}{lccc}
\hline & $\begin{array}{c}\text { EACA } \\
(n=51)\end{array}$ & $\begin{array}{c}\text { Control } \\
(n=52)\end{array}$ & $p$ \\
\hline $\begin{array}{l}\text { Surgeon 1/ } \\
\text { other surgeons }\end{array}$ & $27 / 24(44 \% / 57 \%)$ & $34 / 18(56 \% / 43 \%)$ & 0.2 \\
CABG only & 39 & 38 & NS \\
No. of grafts & $3.80 \pm 0.76$ & $3.63 \pm 0.88$ & NS \\
$\quad$ CABG only) & & & \\
No. of grafts & $3.63 \pm 0.97$ & $3.54 \pm 0.92$ & NS \\
$\quad$ all CABG) & & & \\
ITA graft & 30 & 29 & NS \\
Valve & 10 & 12 & NS \\
Valve per CABG & 4 & 4 & NS \\
CPB time & $148 \pm 41$ & $129 \pm 42$ & 0.02 \\
Crossclamp time & $85 \pm 28$ & $73 \pm 29$ & 0.04 \\
IABP & 5 & 6 & NS \\
Pericardium closed & 8 & 15 & NS \\
Reoperation & 5 & 7 & NS \\
\hline
\end{tabular}

Values are mean \pm standard deviation. $C A B G$, Coronary artery bypass grafting; $N S$, not significant; $L A B P$, intraaortic balloon pump.

conformation does monoclonal antibody F26 bind to fibrinogen. ${ }^{21,22} \mathrm{~F} 26$ binds only to activated, not resting, platelets. ${ }^{21,22}$ Fig. 3 demonstrates the effects of the combination of $20 \mathrm{mmol} / \mathrm{L}$ adenosine diphosphate (ADP) with $20 \mathrm{mmol} / \mathrm{L}$ epinephrine on the platelet surface binding of monoclonal antibody F26, as determined by whole blood flow cytometry. In the absence of ADP and epinephrine, there was little binding of F26 and therefore little platelet activation. This finding demonstrates that CPB did not result in circulating activated platelets, regardless of whether the patient received EACA. After the ex vivo addition of ADP and epinephrine, there was a marked increase in the platelet surface binding of F26. This finding demonstrates that the reactivity of platelets (as determined by their ability to bind fibrinogen in response to $\mathrm{ADP}$ and epinephrine) was unaffected by $\mathrm{CPB}$ and was not significantly affected by whether the patient received EACA. Finally, the platelet surface expression of $P$-selectin was minimal irrespective of whether EACA was used (Fig. 4).

In evaluation of the fibrinolytic system, euglobulin clot lysis time was significantly less depressed in the EACA group than in the control group (Fig. 5). Further evidence of fibrinolytic inhibition by EACA was obtained from the obliteration of the CPBassociated increased in circulating plasma D-dimer in the EACA group (Fig. 6). Plasma fibrinogen fell in both groups, with no difference between the two groups (Fig. 7). Plasma antiplasmin and antithrom- 


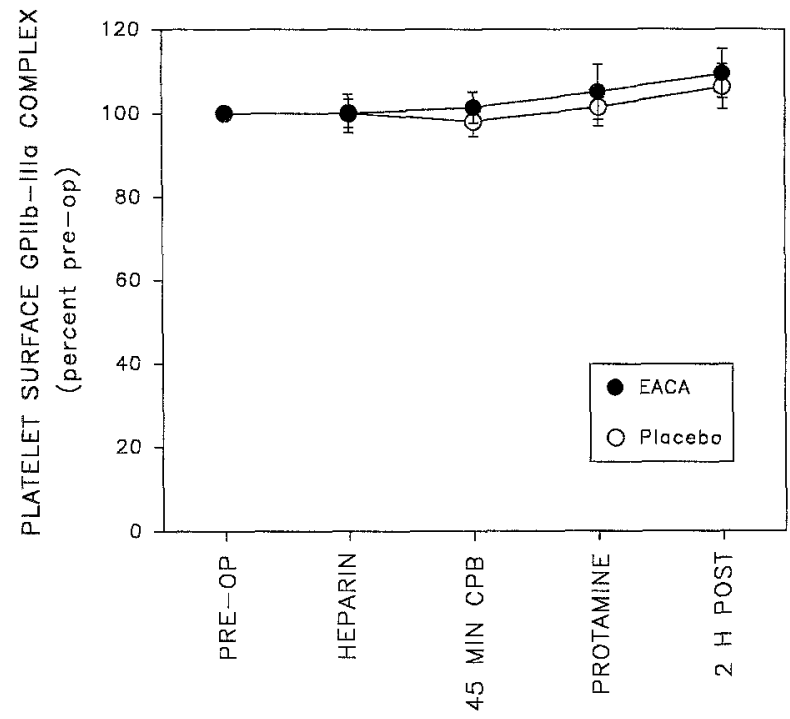

Fig. 2. Platelet surface expression of the GPIIb-IIIa complex (fibrinogen receptor) did not change significantly during or after CPB, irrespective of whether patients received EACA (closed circles) or placebo (open circles). Platelet surface GPIIb-IIIa complex was determined at indicated time points (see Fig. 1) by whole blood flow cytometry with monoclonal antibody $7 \mathrm{E} 3$. Data are mean \pm standard error of the mean; $n=13$ patients for EACA and $n=9$ patients for placebo. Actual preoperative values (mean flourescence \pm standard error of the mean) were $24.2 \pm 1.5$ in EACA group and $20.2 \pm 0.9$ in placebo group.

bin III fell to a similar degree in both groups (Figs. 8 and 9). In these same 26 patients, the platelet count fell during the operation and then rose after operation, with no difference between EACA and placebo groups (data not shown). The preoperative bleeding times were $4.3 \pm 0.74$ minutes in the EACA group and $4.5 \pm 0.26$ minutes in the control group ( $p$ not significant; postoperative bleeding times were $5.3 \pm 0.4$ minutes in the EACA group and $7.2 \pm 1.3$ minutes in the control group ( $p$ not significant). Within each group, the rise in bleeding time from preoperative to postoperative measurements was statistically significant ( $p=0.02$ in both EACA and control groups).

Postoperative bleeding was decreased in the EACA group (Table III). At 12 hours, blood retrieved from the chest tubes was $425 \mathrm{ml}$ in the EACA group and $565 \mathrm{ml}$ in the control group $(p<$ 0.004 ). At 24 hours, blood retrieved from the chest tubes was $647 \mathrm{ml}$ in the EACA group and $839 \mathrm{ml}$ in the control group ( $p=0.002)$. No significant differ-

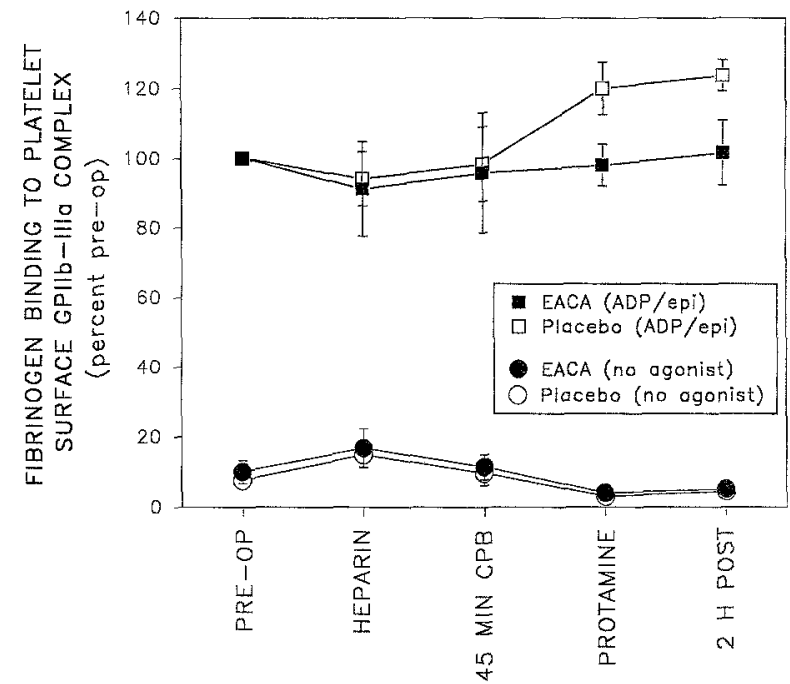

Fig. 3. Irrespective of whether patients received EACA (closed symbols) or placebo (open symbols), platelets circulated during and after CPB with little bound fibrinogen (circles), and platelets were normally reactive to combination of ADP and epinephrine (ADP/epi), as determined by ability to bind fibrinogen to GPIIb-IIIa complex (squares). Fibrinogen binding to platelet surface GPIIb-IIIa complex was determined at indicated time points (see Fig. 1) by whole blood flow cytometry with monoclonal antibody F26. F26 binding to preoperative samples incubated with $20 \mathrm{mmol} / \mathrm{L} \mathrm{ADP}$ and $20 \mathrm{mmol} / \mathrm{L}$ epinephrine was defined as $100 \%$. Data are mean \pm standard error of the mean; $n=12$ patients for EACA and $n=7$ patients for placebo. Preoperative fibrinogen binding to platelet surface GPIIbIIIa complex in absence of agonist (mean flourescence \pm standard error of the mean) was $5.8 \pm 2.3$ in EACA group, and $4.5 \pm 1.3$ in placebo group. Binding with ADP/epi agonist was $39.7 \pm 8.3$ in EACA group and $58.5 \pm 13.9$ in placebo group.

ence, however, was observed in the number of packed red blood cells administered to the two groups during the first 24 hours (0.94 units in the EACA group and 1.12 units in the control group). Neither did any significant difference exist with respect to other blood products (cryoprecipate and fresh-frozen plasma) administered to the two groups. Postoperative hematocrit at discharge and immediate postoperative clotting studies were also similar in the two groups (Table III).

By multivariate analysis, three factors were found to correlate with postoperative blood loss at 24 hours (Table IV). In addition to the use of EACA, surgeon 1 was associated with less bleeding than the other surgeons taken in aggregate $(582$ vs $978 \mathrm{ml}$, 


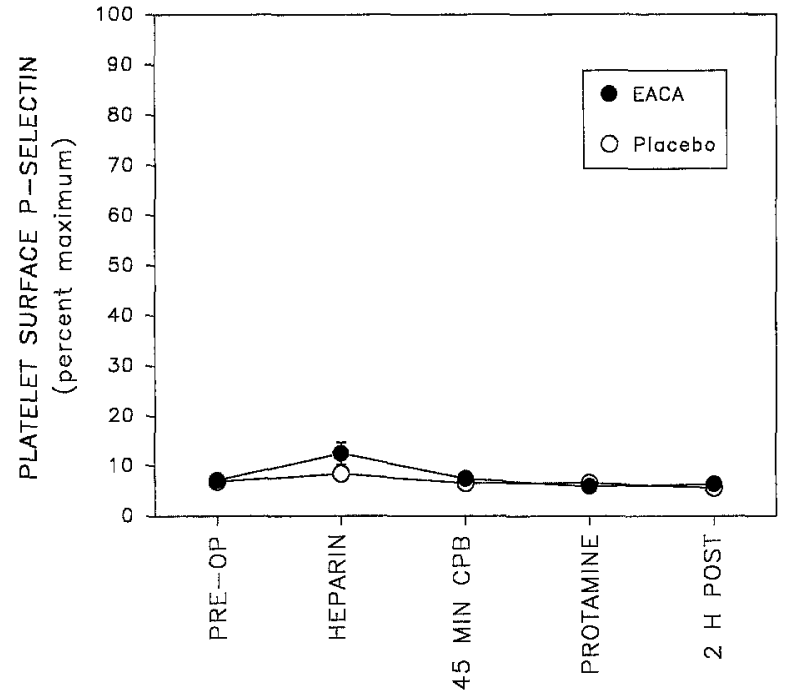

Fig. 4. Platelet surface expression of P-selectin (reflecting granule secretion) was minimal whether patients received EACA (closed circles) or placebo (open circles). Platelet surface P-selectin was determined at indicated time points (see Fig. 1) by whole blood flow cytometry with monoclonal antibody $\mathrm{S} 12$. S12 binding to preoperative samples incubated with $2 \mathrm{U} / \mathrm{ml}$ thrombin was defined as $100 \%$. Data are mean \pm standard error of the mean; $n=12$ patients for EACA and $n=9$ patients for placebo. Preoperative values (mean flourescence \pm standard error of the mean) were $2.7 \pm 0.4$ in EACA group and $2.6 \pm 1.8$ in placebo group.

$p=0.002$ ). Patients with intraaortic balloon pump (IABP) use had increased blood loss compared with patients not requiring an IABP (1410 vs $664 \mathrm{ml}, p=$ $0.02)$. Despite the fact that a disproportionate number of the patients in the control group were performed by the surgeon with the lowest bleeding rate, the EACA group had less bleeding. Although CPB time and crossclamp time were longer in the EACA group by univariate analysis, by multivariate analysis, these factors were not found to be associated with postoperative bleeding.

Although the blood transfusion requirement did not differ significantly between the EACA and control groups, two other variables did affect blood use during the first 24 hours (Table V). Men received a mean of 0.78 units of packed red cells compared with women, who received 1.68 units $(p=0.0001)$. When normalized for body surface area, the packed red cells were 0.41 per patient $/ \mathrm{m}^{2}$ for men and 0.98 per patient $/ \mathrm{m}^{2}$ for women. Patients undergoing primary operation received 0.84 units, compared with 2.42 units for patients undergoing reoperation $(p=$

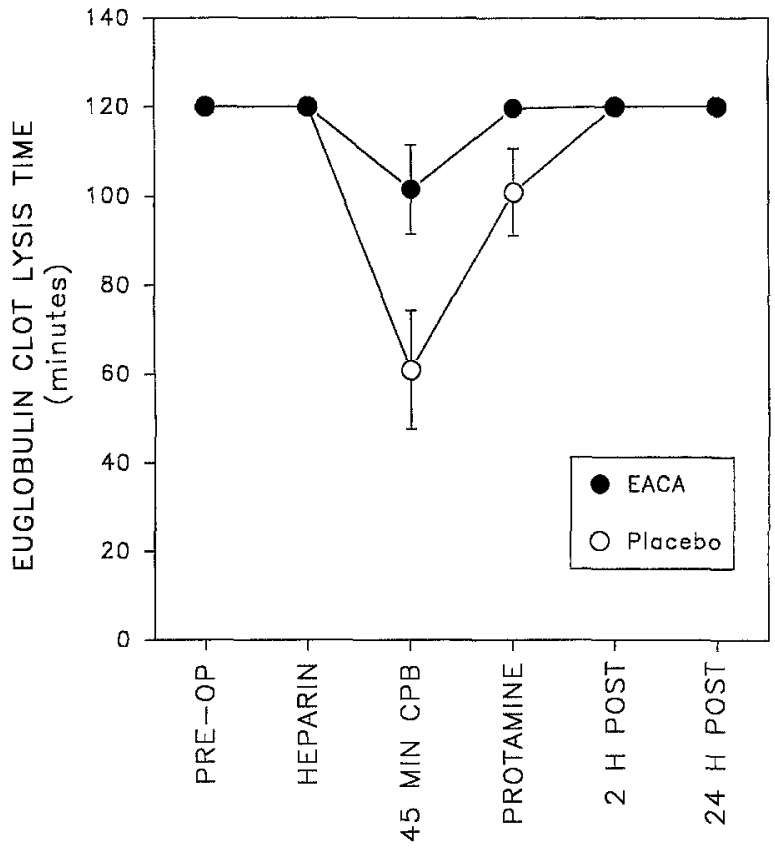

Fig. 5. Euglobulin clot lysis time, assay of fibrinolytic activity, was significantly longer, indicating less fibrinolysis in patients receiving EACA (closed circles) than in control patients (open circles). Time points as given in Fig. 1. Data are mean \pm standard error of the mean; $n=14$ patients for EACA and $n=11$ patients for placebo.

$0.005)$. To assess the possibility that smaller preoperative red cell mass in the women led to a greater proportion of red cell mass lost and therefore a greater transfusion requirement, a metric was constructed that measured the relative proportion of the red cell mass lost. This metric was calculated by dividing the 24 hour blood loss by the product of the preoperative hematocrit and body weight. This relative measure was 0.24 in men and 0.25 in women. The difference in red cell transfusions between men and women cannot be explained by a difference in the proportion of the preoperative red cell mass lost.

Similarly, patients requiring an IABP received 2.64 units of packed red cells, compared with 0.83 units for those not requiring an IABP $(p=0.008)$. One patient died in the EACA group and none died in the placebo group. The single death was that of a 71-year-old woman 3 days after reoperative coronary artery bypass grafting when free rupture of the posterior left ventricle occurred as a result of a perioperative myocardial infarction. All coronary grafts were patient at autopsy.

Other than the decreased bleeding in the EACA group, no differences in complications were ob- 


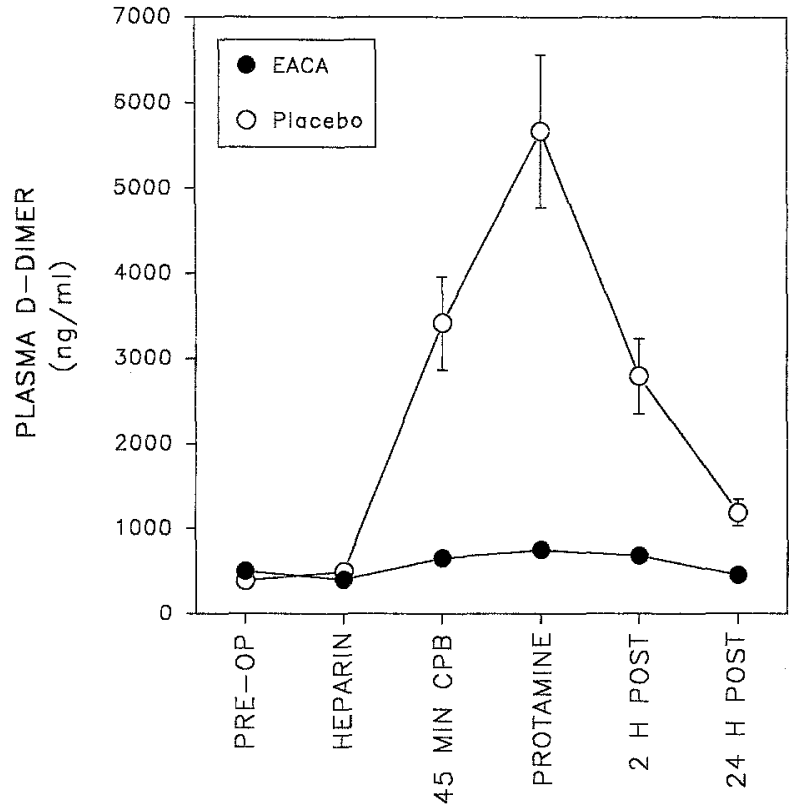

Fig. 6. Administration of EACA inhibited fibrinolysis, as evidenced by obliteration of CPB-associated increase in circulating plasma D-dimer. Time points as given in Fig. 1. Data are mean \pm standard error of the mean; $n=14$ patients for EACA and $n=10$ patients for placebo.

served between control and EACA groups. Although a trend toward higher increased prevalence of electrocardiographically diagnosed myocardial infarction (new $Q$ waves or loss of $R$ waves) in the EACA group than in the control group (5 of 51 vs 2 of $52 ; p=0.08$ ) was observed, this difference was not statistically significant. Furthermore, no differences in postoperative creatine kinase level or creatine kinase index were seen between the two groups. No cerebrovascular accidents occurred in the EACA group; two occurred in the control group ( $p=0.33)$. One patient in the EACA group and three in the control group required reexploration for postoperative bleeding $(p=0.6)$.

\section{Discussion}

Multiple factors contribute to the bleeding diathesis seen after cardiac operations performed with CPB. Not all are understood, and there is disagreement regarding their relative importance. The two major hematologic abnormalities leading to increased postoperative hemorrhage are decreased platelet function and increased fibrinolysis. ${ }^{24-26}$ Bleeding time increases during and after CPB. This was long considered to reflect an intrinsic platelet defect caused by the nonphysiologic nature of CPB,

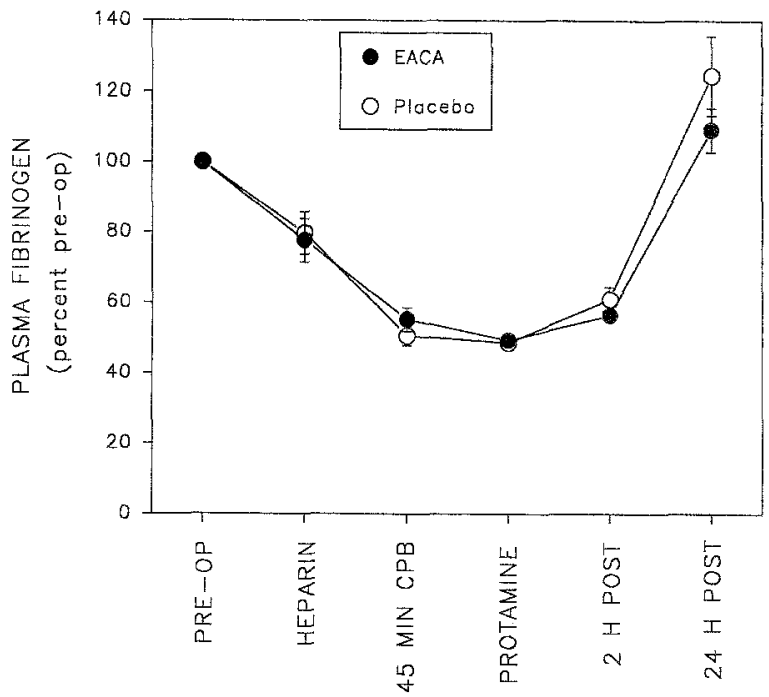

Fig. 7. Plasma fibrinogen levels decreased during CPB, irrespective of whether patients received EACA (closed circles) or placebo (open circles). Time points as given in Fig. 1. Data are mean \pm standard error of the mean; $n=$ 14 patients for EACA and $n=12$ patients for placebo. Actual preoperative values ( \pm standard error of the mean) were $405.3 \pm 33.9 \mathrm{mg} / \mathrm{dl}(\mathrm{EACA})$ and $313.8 \pm 36.6$ $\mathrm{mg} / \mathrm{dl}$ (placebo).

but Kestin and associates ${ }^{27}$ have proposed that the platelet defect occurs because of an antagonistic external force, such as cold, or lack of availability of platelet agonists. Previous studies that used whole blood flow cytometry failed to show any loss of platelet membrane receptors, ${ }^{27}$ but studies of platelet-rich plasma or washed platelets do show such alterations. $^{28,29}$ This difference is likely to be the result of artifactual in vitro changes in platelet membrane receptors caused by the separation procedures required for the preparation of platelet-rich plasma and washed platelets.

The mechanism of the fibrinolysis is more clearly understood. ${ }^{24,26,30}$ Blood coming into contact with foreign surfaces in the CPB circuit initiates the contact phase of coagulation and generates kallikrein. This in turn stimulates bradykinin release, and both molecules activate tissue plasminogen activator, which converts plasminogen to plasmin, a potent fibrinolytic and fibrinogenolytic agent. Heparin also directly increases plasmin activity. Further consequences of CPB are a reduction in circulating $\alpha_{2}$-antiplasmin and an increase in circulating plasminogen activator inhibitor $-1 .{ }^{31}$

Aprotinin has been shown by numerous studies to reduce bleeding after cardiac operations., $1,2,32$ It 


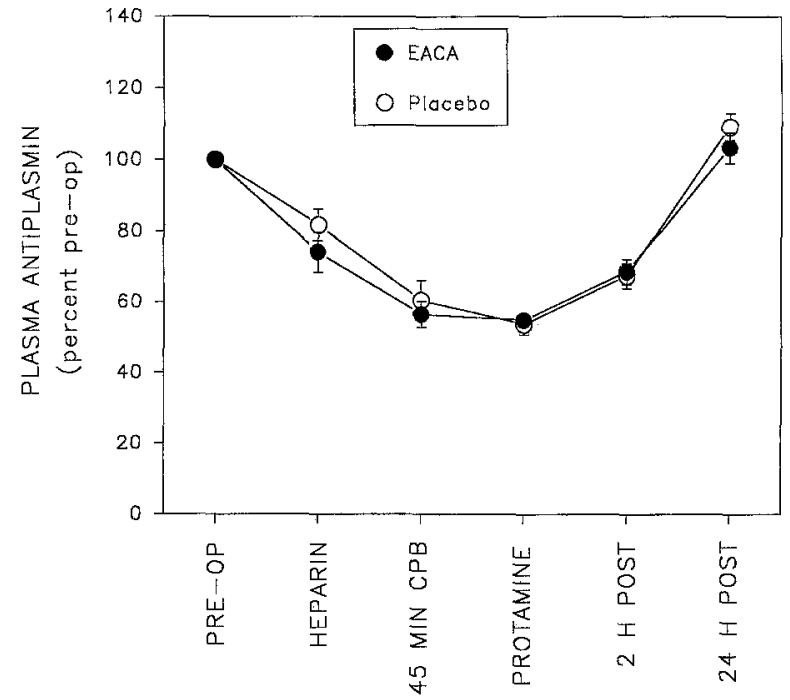

Fig. 8. Plasma antiplasmin levels decreased during $\mathrm{CPB}$, irrespective of whether patients received EACA (closed circles) or (open circles). Time points as given in Fig. 1. Data are mean \pm standard error of the mean; $n=14$ patients for EACA and $n=12$ patients for placebo. Actual preoperative values (percentage of mean values in normal volunteers \pm standard error of the mean) were $92.3 \% \pm 4.5 \%$ (EACA) and $85.0 \% \pm 2.5 \%$ (placebo).

Table III. Postoperative blood loss, transfusions, coagulation values, hematocrit, and reexploration in the EACA and control groups

\begin{tabular}{lccc}
\hline & \multicolumn{1}{c}{ EACA } & \multicolumn{1}{c}{ Control } & $p$ \\
\hline Blood loss, 12 hr (ml) & $425 \pm 412$ & $565 \pm 488$ & 0.004 \\
Blood loss, 24 hr & $647 \pm 488 \mathrm{ml}$ & $839 \pm 634 \mathrm{ml}$ & 0.002 \\
Units RBC, 24 hr & $1.13 \pm 1.37$ & $1.35 \pm 2.02$ & NS \\
Units FFP, 24 hr & $0.2 \pm 0.8$ & $0.38 \pm 1.24$ & NS \\
Hematocrit at discharge & $29.9 \pm 3.6$ & $29.8 \pm 3.2$ & NS \\
$\quad(\%)$ & & & \\
PT (postoperative) (sec) & $14.1 \pm 1.0$ & $14.0 \pm 1.3$ & NS \\
PTT (postoperative) & $34.5 \pm 6.2$ & $35.0 \pm 9.2$ & NS \\
$\quad$ & & & \\
TT (sec) (postoperative) (sec) & $19.0 \pm 5.4$ & $17.4 \pm 8.5$ & NS \\
Reexploration (bleeding) & 1 & 3 & NS
\end{tabular}

Values are mean \pm standard deviation. $R B C$, Red blood cells; $N S$, not significant; FFP, fresh-frozen plasma; $P T$, prothrombin time; $P T T$, partial thromboplastin time; $T T$, thrombin time.

interrupts several steps in the cascade of hematologic changes during CPB that lead to the bleeding diathesis. ${ }^{26,33-38}$ These salutary effects occur at least in part as a result of aprotinin's direct antiplasmin activity, its inhibition of kallikrein, its inhibition of urokinase, and its preservation of normal levels of $\alpha_{2}$-antiplasmin. Aprotinin has also been reported to

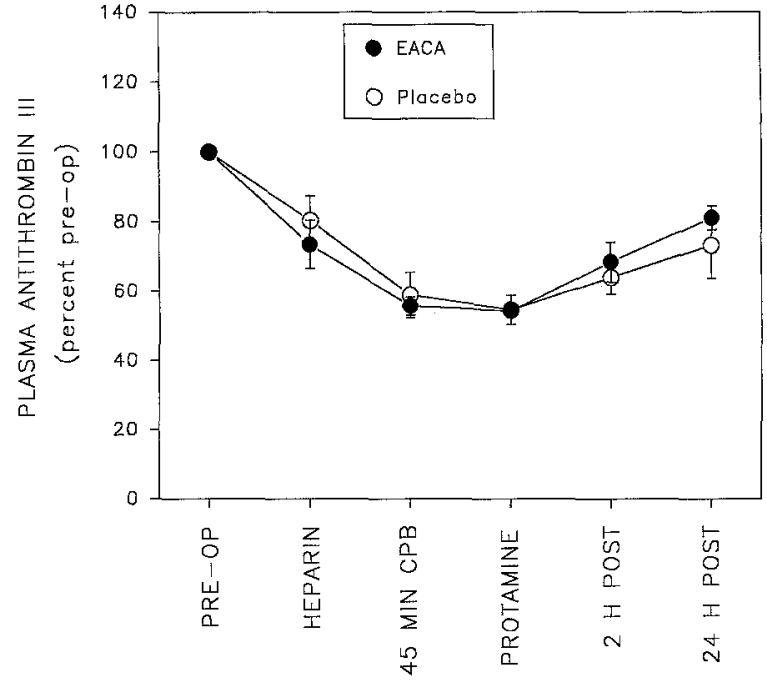

Fig. 9. Plasma antithrombin III levels decreased during CPB, irrespective of whether patients received EACA (closed circles) or placebo (open circles). Time points as given in Fig. 1. Data are mean \pm standard error of the mean; $n=$ 10 patients for EACA and $n=7$ patients for placebo. Actual preoperative values (percentage of mean values in normal volunteers \pm standard error of the mean) were $94.2 \% \pm$ $7.1 \%$ (EACA) and $85.1 \% \pm 3.3 \%$ (placebo).

preserve platelet function, ${ }^{1,29}$ although other reports suggest that its role in platelet preservation is absent or minimal compared with its interruption of fibrinolysis. ${ }^{39,40}$ Although it is of unquestioned value in reducing blood loss, aprotinin is expensive. Questions have also been raised about its safety. Suggestions that aprotinin causes abnormal intravascular clotting, leading to organ dysfunction, have been made by several investigators. ${ }^{2-4}$ For these two reasons we investigated the ability of EACA to reduce postoperative bleeding and also the mechanism of its action. EACA exerts its antifibrinolytic effect by binding with plasminogen and plasmin, displacing them from fibrin. ${ }^{24}$ It also inhibits tissue plasminogen activator activity. ${ }^{6}$ Because plasmin reduces the platelet GPIb receptors ${ }^{41}$ and thus reduces platelet adhesion, and because the fibrin degradation products of fibrinolysis also inhibit platelet function, we measured the effect of EACA on platelet function in 26 patients by means of detailed hematologic testing.

In this study, the platelet surface expressions of P-selectin, GPIb, the GPIIb-IIIa complex, and fibrinogen binding to platelet surface GPIIb-IIIa were all unaffected by the administration of EACA 
Table IV. Multivariate analysis: Effect of operative and patient variables on blood loss

\begin{tabular}{lcc}
\hline \multicolumn{1}{c}{ Variable } & Blood loss at $24 \mathrm{hr}(\mathrm{ml})$ & $p$ \\
\hline Surgeon 1 & $582 \pm 262$ & 0.003 \\
Other surgeons & $978 \pm 786$ & \\
EACA & $647 \pm 488$ & 0.002 \\
Control & $839 \pm 634$ & \\
IABP & $1410 \pm 1089$ & 0.02 \\
No IABP & $664 \pm 419$ & \\
Pericardium closed & $562 \pm 280$ & 0.2 \\
Pericardium left open & $796 \pm 622$ & \\
Male & $792 \pm 575$ & 0.2 \\
Female & $615 \pm 551$ & \\
Blood loss adjusted for BSA & & \\
$\quad$ Male & $400 \pm 310$ & 0.5 \\
$\quad$ Female & $354 \pm 329$ & \\
Reoperation & $972 \pm 738$ & 0.1 \\
Primary operation & $714 \pm 544$ & \\
\hline
\end{tabular}

Multivariate analysis. Values are mean \pm standard deviation. $I A B P$, Intraaortic balloon pump; $B S A$, body surface area.

to patients during CPB. Each of these antigens is of functional importance. P-selectin, an $\alpha$-granule membrane protein that is expressed on the platelet surface only after degranulation, ${ }^{14,16}$ mediates adhesion of activated platelets to neutrophils and monocytes. ${ }^{42,43}$ GPIb, a receptor for von Willebrand factor, is critical for platelet adhesion to damaged blood vessel walls. ${ }^{44}$ The GPIIb-IIIa complex, a receptor for fibrinogen, von Willebrand factor, and fibronectin, is critical for platelet aggregation. ${ }^{45}$ The lack of any effect of EACA on Pselectin, GPIb, the GPIIb-IIIa complex, and fibrinogen binding to the GPIIb-IIIa complex strongly suggests that the EACA-dependent decrease in CPB-associated blood loss is not mediated through a platelet-dependent mechanism.

We examined the fibrinolytic system in the same subset of the study population. In the control group, evidence of increased fibrinolysis was seen. This has been previously reported during $\mathrm{CPB} .^{26} \mathrm{We}$ found a marked increase in plasma $\mathrm{D}$-dimer concentrations and a corresponding drop in euglobulin lysis time in the control group; in the EACA group no change occurred in D-dimer concentrations, and although the euglobulin clot lysis time fell slightly, it did so to a lesser extent than in the control group.

The major end point of the study was postoperative bleeding. At both 12 hours and 24 hours after operation, univariate and multivariate analyses demonstrated a significant reduction in blood loss in the EACA group. This is consistent with our previous study and several other studies, which showed
Table V. Multivariate analysis: Effect of operative and patient variables on blood transfusions given

\begin{tabular}{lcc}
\hline \multicolumn{1}{c}{ Variable } & Blood given (units/24 hr $)^{*}$ & $p$ \\
\hline Male & $0.78 \pm 1.40$ & 0.0001 \\
Female & $1.68 \pm 1.25$ & \\
Primary operation & $0.84 \pm 1.17$ & 0.005 \\
Reoperation & $2.42 \pm 2.19$ & \\
No IABP & $0.83 \pm 1.10$ & 0.008 \\
IABP & $2.64 \pm 2.42$ & \\
EACA & $0.94 \pm 1.21$ & 0.3 \\
Control & $1.12 \pm 1.58$ & \\
Surgeon 1 & $0.87 \pm 1.16$ & 0.5 \\
Other surgeons & $1.28 \pm 1.71$ & \\
\hline
\end{tabular}

Multivariate analysis. Values are mean \pm standard deviation. $I A B P$, Intraaortic balloon pump.

*Packed red blood cell units.

reduced bleeding as a result of EACA use. ${ }^{6,7,9-11}$ We assessed bleeding by directly measuring chest tube effluent. When these measurements were normalized for body surface area, the conclusions did not change.

In our previous study of $\mathrm{EACA}^{11}$ we limited the patient population to those patients undergoing elective coronary artery bypass operations, as did Daily and colleagues ${ }^{10}$ in their recent publication. Because the difference in bleeding at 12 hours between the control $(332 \mathrm{ml})$ and EACA $(272 \mathrm{ml})$ groups in our earlier study was statistically significant but clinically insubstantial, we broadened the inclusion group in the current study. All patients undergoing coronary bypass operations, valve operations, or a combination of the two were included. Pregnant women, patients with known bleeding disorders, and patients requiring emergency operation were excluded.

Bleeding after heart operations is a problem of such magnitude that it is curious that little recognition or importance seems to have been given to reports demonstrating the efficacy of EACA published during the infancy of cardiac surgery. In 1967, Sterns and Lillehei $^{5}$ almost halved postoperative bleeding by giving EACA at the conclusion of CPB. In 1976, Lambert and colleagues ${ }^{8}$ showed prompt resolution of established postoperative bleeding after EACA treatment. The interest in aprotinin therapy may have rekindled interest in EACA.

This rekindled interest assumes greater significance as a result of the current focus on medical costs. Purchased through our hospital pharmacy, the commonly used high-dose aprotinin regimen $(20 \times$ $10^{6} \mathrm{kIU}$ before bypass, $20 \times 10^{6} \mathrm{kIU}$ in heart-lung 
pump, and $5 \times 10^{6} \mathrm{kIU} / \mathrm{hr}$ after 1 hour for the duration of the operation) costs our hospital $\$ 150$ per $10 \times 10^{6} \mathrm{kIU}$, or about $\$ 785$ per patient. A 30 gm dosage of EACA (the total dose used in this study) costs our hospital $\$ 6.96$-a difference between the two drugs of about $\$ 778$ per patient. This cost differential places aprotinin at a considerable disadvantage in the choice between the two drugs on the basis of a cost-benefit analysis.

As in our previous investigation of EACA, ${ }^{11}$ we found no morbidity associated with the drug. Other studies have also shown no increase in complications from EACA use. ${ }^{7,9,10}$ Because of the statistically insignificant increase in perioperative myocardial infarctions in the treatment group, however, this question must still be considered unanswered. With only 103 enrolled patients, it is possible that the study lacked sufficient statistical power to detect other differences in complication rates between the two groups.

Increased attention to control of bleeding in the terminal stages of the operation may be one cause of decreased postoperative bleeding. Although such increased attention cannot be measured directly, the operative time spent after the patient has been weaned from $\mathrm{CPB}$ and all the cardiac portions of the operation have been completed could be used as a surrogate measure. There was no difference in closure time (termination of CPB to dressing application) between the EACA and control groups. An unexpected and unexplained finding in this study was that the patients of one surgeon (surgeon 1) had significantly less bleeding than did those of the other surgeons. We have since discovered that this result parallels that in our total patient database extending back several years. In this study, the closure time for surgeon 1 was slightly but not significantly less than for the aggregate of the other surgeons. We therefore could not conclude that extra time (or care) in closing contributed to the difference in bleeding.

We conclude that EACA reduces postoperative bleeding after heart operations at far less expense than aprotinin and with no detectable morbidity. The EACA-dependent decrease in the CPB-associated blood loss is mediated by inhibition of the fibrinolytic system, not by a platelet-dependent mechanism.

We thank Drs. Barry S. Coller and Harvey Gralnick for generously providing monoclonal antibodies, Drs. Anne M. Stoddard and Frederick A. Anderson, Jr., for performing the statistical evaluation, and Marc Barnard, MS, and
Hollace MacGregor, BS, for performing the hematologic and fibrinolytic analyses.

\section{REFERENCES}

1. van Oeveren W, Jansen NJ, Bidstrup BP, Royston D, Westaby S, Neuhof H, et al. Effects of aprotinin on hemostatic mechanisms during cardiopulmonary bypass. Ann Thorac Surg 1987;44:640-5.

2. Cosgrove DM 3rd, Heric B, Lytle BW, Taylor PC, Novoa R, Golding LA, et al. Aprotinin therapy for reoperative myocardial revascularization: a placebo-controlled study. Ann Thorac Surg 1992;54:1031-6. Comment in Ann Thorac Surg 1993;56:198.

3. Laub GW, Riebman JB, Anderson WA, Fernandez J, McGrath LB. The impact of aprotinin on coronary artery bypass graft patency. Chest 1994;106:1370-5.

4. Sundt TM 3rd, Kouchoukos NT, Saffitz JE, Murphy SF, Wareing TH, Stahl DJ. Renal dysfunction and intravascular coagulation with aprotinin and hypothermic circulatory arrest. Ann Thorac Surg 1993;55:1418-24.

5. Sterns LP, Lillehei CW. Effect of epsilon aminocaproic acid upon blood loss following open-heart surgery: an analysis of 340 patients. Can J Surg 1967;10:304-7.

6. Gans $\mathrm{H}$, Krivit W. Problems in hemostasis during open-heart surgery. III: episilon amino caproic acid as an inhibitor of plasminogen activator activity. Ann Surg 1962;155:268-76.

7. DelRossi AJ, Cernaianu AC, Botros S, Lemole GM, Moore R. Prophylactic treatment of postperfusion bleeding using EACA. Chest 1989;96:27-30.

8. Lambert $\mathrm{CJ}$, Marengo-Rowe AJ, Leveson JE, Green RH, Thiele JP, Geisler GF, et al. The treatment of postperfusion bleeding using epsilon-aminocaproic acid, cryoprecipitate, fresh-frozen plasma, and protamine sulfate. Ann Thorac Surg 1979;28:440-4.

9. Arom KV, Emery RW. Decreased postoperative drainage with addition of epsilon-aminocaproic acid before cardiopulmonary bypass. Ann Thorac Surg 1994;57:1108-12.

10. Daily PO, Lamphere JA, Dembitsky WP, Adamson RM, Dans NF. Effect of prophylactic epsilon-aminocaproic acid on blood loss and transfusion requirements in patients undergoing first-time coronary artery bypass grafting: a randomized; prospective, double-blind study. J Thorac Cardiovase Surg 1994;108:99-106.

11. Vander Salm TJ, Ansell JE, Okike ON, Marsicano TH, Lew $\mathrm{R}$, Stephenson WP, et al. The role of epsilon-aminocaproic acid in reducing bleeding after cardiac operation: a doubleblind randomized study. J Thorac Cardiovase Surg 1988;95: 538-40.

12. Khuri SF, Wolfe JA, Josa M, Afford TC, Szymanski I, Assousa S, et al. Hematologic changes during and after cardiopulmonary bypass and their relationship to the bleeding time and nonsurgical blood loss. J Thorac Cardiovasc Surg 1992;104:94-107.

13. Michelson AD, Ellis PA, Barnard MR, Matic GB, Viles AF, Kestin AS. Downregulation of the platelet surface glycoprotein Ib-IX complex in whole blood stimulated by thrombin, adenosine diphosphate, or an in vivo wound. Blood 1991;77: 770-9.

14. Stenberg PE, McEver RP, Shuman MA, Jacques YV, Bainton DF. A platelet alpha-granule membrane protein (GMP140 ) is expressed on the plasma membrane after activation. $J$ Cell Biol 1985;101:880-6. 
15. Bevilacqua M, Butcher E, Furie B, Furie B, Gallatin M, Gimbrone $\mathrm{M}$, et al. Selectins: a family of adhesion receptors [letter]. Cell 1991;67:233.

16. McEver RP. Properties of GMP-140, an inducible granule membrane protein of platelets and endothelium. Blood Cells 1990;16:73-80.

17. Coller BS, Peerschke EI, Scudder LE, Sullivan CA. Studies with a murine monoclonal antibody that abolishes ristocetininduced binding of von Willebrand factor to platelets: additional evidence in support of GPIb as a platelet receptor for von Willebrand factor. Blood 1983;61:99-110.

18. Michelson AD, Loscalzo J, Melnick B, Coller BS, Handin RI. Partial characterization of a binding site for von Willebrand factor on glycocalicin. Blood 1986;67:19-26.

19. Gatter KC, Cordell JL, Turley H, Heryet A, Kieffer N, Anstee DJ, et al. The immunohistological detection of platelets, megakaryocytes and thrombi in routinely processed specimens. Histopathology 1988;13:257-67.

20. Coller BS. A new murine monoclonal antibody reports an activation-dependent change in the conformation and/or microenvironment of the platelet glycoprotein IIb/IIIa complex. J Clin Invest 1985;76:101-8.

21. Gralnick HR, Williams S, McKeown L, Connaghan G, Shafer B, Hansmann K, et al. Endogenous platelet fibrinogen surface expression on activated platelets. J Lab Clin Med 1991;118:604-13.

22. Gralnick HR, Williams SB, McKeown L, Shafer B, Connaghan GD, Hansmann $\mathrm{K}$, et al. Endogenous platelet fibrinogen: its modulation after surface expression is related to size-selective access to and conformational changes in the bound fibrinogen. Br J Haematol 1992;80:347-57.

23. Shattil SJ, Cunningham M, Hoxie JA. Detection of activated platelets in whole blood using activation-dependent monoclonal antibodies and flow cytometry. Blood 1987;70: 307-15.

24. Hardy J, Desroches J. Natural and synthetic antifibrinolytics in cardiac surgery. Can J Anaesth 1992;39:353-65.

25. Michelson AD. Pathomechanism of defective hemostasis during and after extracorporeal circulation: the role of platelets. In: Friedel N, Hetzer R, Royston D, editors. Blood use in cardiac surgery. Darmstadt, Germany: Steinkopff Verlag, 1991:16-26.

26. Khuri SF, Michelson AD, Valeri CR. Effects of cardiopulmonary bypass on hemostasis. In: Loscalzo J, Schafer AI, editors. Thrombosis and hemorrhage. Cambridge, England: Blackwell, 1993:1051-73.

27. Kestin AS, Valeri CR, Khuri SF, Loscalzo J, Ellis PA, MacGregor $\mathrm{H}$, et al. The platelet function defect of cardiopulmonary bypass. Blood 1993;82:107-17.

28. Wenger RK, Lukasiewicz H, Mikuta BS, Niewiarowski S, Edmunds LH. Loss of platelet fibrinogen receptors during clinical cardiopulmonary bypass. J Thorac Cardiovasc Surg 1989;97:235-9.
29. van Oeveren W, Harder MP, Roozendaal KJ, Eijsman L, Wildevuur CR. Aprotinin protects platelets against the initial effect of cardiopulmonary bypass. J Thorac Cardiovasc Surg 1990;99:788-96.

30. Kirklin JW, Barratt-Boyes BG. Cardiac surgery. 2nd ed. New York: Churchill Livingstone, 1993:88.

31. Ray MJ, Marsh NA, Hawson GA. Relationship of fibrinolysis and platelet function to bleeding after cardiopulmonary bypass. Blood Coagul Fibrinolysis 1994;5:679-85.

32. Royston D, Bidstrup BP, Taylor KM, Sapsford RN. Effect of aprotinin on need for blood transfusion after repeat openheart surgery. Lancet 1987;2:1289-91.

33. Westaby S. Aprotinin in perspective. Ann Thorac Surg 1993;55:1033-41.

34. Royston D. The serine antiprotease aprotinin (Trasylol); a novel approach to reducing postoperative bleeding. Blood Coagul Fibrinolysis 1990;1:55-69.

35. Royston D. Aprotinin prevents bleeding and has effects on platelets and fibrinolysis. J Cardiothorac Vasc Anesth 1991; 5:18-23.

36. Edmunds LH Jr. Invited letter concerning: aprotinin's effect in cardiopulmonary bypass [letter]. J Thorac Cardiovase Surg 1993;106:748-9.

37. Edmunds LH Jr, Niewiarowski S, Colman RW. Invited letter concerning: aprotinin [letter]. J Thorac Cardiovasc Surg 1991;101:1103-4.

38. Blauhut B, Lundsgaard-Hansen P. Reply to invited letter concerning: aprotinin ( J Thorac Cardiovase Surg 1991; 101:1103-4) [letter]. J Thorac Cardiovasc Surg 1992;103: 386-7.

39. Orchard MA, Goodchild CS, Prentice CR, Davies JA, Benoit $\mathrm{SE}$, Creighton-Kemsford LJ, et al. Aprotinin reduces cardiopulmonary bypass-induced blood loss and inhibits fibrinolysis without influencing platelets. Br J Haematol 1994;85:533-41.

40. Marx G, Pokar H, Reuter H, Doering V, Tilsner V. The effects of aprotinin on hemostatic function during cardiac surgery. J Cardiothorac Vasc Anesth 1991;5:467-74.

41. Michelson AD, Barnard MR. Plasmin-induced redistribution of platelet glycoprotein $\mathrm{Ib}$. Blood 1990;76:2005-10.

42. Larsen E, Celi A, Gilbert GE; Furie BC, Erban JK, Bonfanti $R$, et al. PADGEM protein: a receptor that mediates the interaction of activated platelets with neutrophils and monocytes. Cell 1989;59:305-12.

43. Palabrica T, Lobb R, Furie BC, Aronovitz M, Benjamin C, Hsu YM, et al. Leukocyte accumulation promoting fibrin deposition is mediated in vivo by P-selectin on adherent platelets. Nature 1992;359:848-51.

44. Ruggeri ZM. The platelet glycoprotein Ib-IX complex: Progr Hemost Thromb 1991;10:35-68.

45. Phillips DR, Charo IF, Parise LV, Fitzgerald LA. The platelet membrane glycoprotein IIb-IIIa complex. Blood 1988;71:831-43. 